\title{
REAKSI HARGA SAHAM TERHADAP PERUBAHAN DIVIDEN TUNAI DAN DIVIDEND YIELD DI BURSA EFEK JAKARTA
}

\author{
Sri Mulyati \\ Fakultas Ekonomi \\ Universitas Islam Indonesia
}

\begin{abstract}
Abstrak
Penelitian ini merupakan penelitian empiris tentang reaksi harga saham terhadap perubahan dividen tunai dan dividend yields di Bursa Efek Jakarta. Tujuan yang ingin dicapai pada penelitian ini adalah: pertama, untuk menguji apakah harga saham bereaksi positif terhadap pengumuman kenaikkan dividen dan bereaksi negatif terhadap pengumuman penurunan dividen. Kedua, untuk menguji apakah reaksi harga saham yang terjadi dipengaruhi oleh perubahan dividend yield.

Penelitian ini menggunakan sampel sebanyak 52 saham perusahaan yang terdiri dari 27 perusahaan yang membayar dividen naik dan 25 perusahaan yang membayar dividen turun. Periode pengamatan pada penelitian ini adalah tahun 1995 dan 1996. data yang digunakan berupa data sekunder yang terdiri dari data harga saham perusahaan, Indeks Harga Saham Gabungan, dividen per lembar saham dan data dividend yield perusahaan. Abonormal return dihitung dengan menggunakan model pasar. Metode statistik yang digunakan untuk pengujian hipotesis adalah uji t.

Hasil penelitian menunjukkan bahwa (1) reaksi harga saham positif terhadap kenaikkan dividen yang dibayarkan terjadi pada hari ke 5 sebelum pengumuman, sedangkan reaksi harga saham negatif terhadap penurunan dividen yang dibayarkan terjadi pada hari ke 5 setelah pengumuman. Ini menunjukkan bahwa pengumuman dividen mengandung informasi. (2) reaksi harga saham tidak dipengaruhi oleh perubahan dividend yield, ini ditunjukkan dari tidak adanya koefisien yang signifikan.
\end{abstract}

\section{PENDAHULUAN}

Tujuan investor yang menginvestasikan dananya di pasar modal adalah untuk memperoleh imbalan atau pendapatan dari dana yang diinvestasikan. Bagi investor yang menginvestasikan dananya pada saham suatu perusahaan bertujuan untuk memperoleh pendapatan yang berupa dividen atau capital gain. Dividen adalah pendapatan yang diperoleh setiap periode selama saham masih dimiliki, sedangkan capital gain adalah pendapatan yang diperoleh karena harga jual saham lebih tinggi daripada harga belinya, pendapatan ini baru diperoleh jika saham dijual. Bagi investor yang bertujuan mendapatkan capital gains juga memerlukan informasi tentang dividen, karena dividen merupakan salah satu faktor penting yang dapat mempengaruhi harga saham. Oleh karena itu perusahaan yang sudah go public mempunyai kewajiban untuk memberikan informasi mengenai kinerjanya kepada investor dalam bentuk laporan keuangan dan pengumuman besarnya dividen yang dibayarkan. 
Pengumuman perubahan dividen tunai dan dividend yield diharapkan menimbulkan reaksi harga saham karena dengan adanya reaksi berarti pengumuman tersebut dianggap mempunyai kandungan informasi. Reaksi harga saham ditunjukkan dengan adanya perubahan harga saham yang bersangkutan. Reaksi harga saham dapat diukur dengan menggunakan return saham sebagai nilai perubahan harga atau dengan menggunakan abnormal return. Apabila abnormal return digunakan sebagai pengukur reaksi harga saham, maka pengumuman perubahan dividen dikatakan mempunyai kandungan informasi bila memberikan abnormal return yang signifikan kepada pasar. Sebaliknya, pengumuman perubahan dividen dikatakan tidak mempunyai kandungan informasi bila tidak memberikan $a b$ normal return yang signifikan kepada pasar.

Dividend Signaling Model yang dikemukakan oleh Bhattacharya (1979) merupakan salah satu model yang mendasari dugaan bahwa pengumuman perubahan dividen tunai mempunyai kandungan informasi yang mengakibatkan adanya reaksi harga saham. Model ini menjelaskan bahwa informasi tentang perubahan yang dibayarkan digunakan oleh investor sebagai signal tentang prospek perusahaan di masa yang akan datang. Hal ini disebabkan karena adanya asymmetric information antara manajer dengan investor, sehingga para investor menggunakan kebijakan deviden sebagai indikator tentang prospek perusahaan. Peningkatan dividen yang dibayarkan dianggap sebagai signal yang menguntungkan, sehingga menimbulkan reaksi harga saham yang positif. Sebaliknya penurunan dividen yang dibayarkan dianggap sebagai signal bahwa prospek perusahaan kurang menguntungkan, sehingga menimbulkan reaksi harga saham yang negatif. Suatu penelitian menunjukkan bahwa pengaruh reaksi negatif lebih besar daripada pengaruh reaksi positif, karena bila dividen tunai yang dibayarkan menurun maka rata-rata penurunan harga saham sebesar 3,76\%, sedangkan bila dividen tunai yang dibayarkan meningkat maka harga saham naik sebesar 0,72\% (Aharony dan Swary, 1980).

Penelitian mengenai dugaan bahwa pengumuman perubahan dividen mengandung informasi bagi pasar memberikan hasil yang berlainan. Watts (1973) dan Gonedes (1978) tidak menemukan bukti bahwa pengumuman dividen mengandung informasi, hal ini ditunjukkan dengan abnormal return yang diberikan kepada pasar tidak signifikan. Sedangkan penelitian terbaru yang dilakukan oleh Aharony dan Swary (1980), Woolrige (1982), Petit (1972), Asquith dan Mullins (1983), Eades, Hess dan Kim (1984) mendukung bahwa pengumuman perubahan dividen yang dibayarkan mengandung informasi, hal ini ditunjukkan dengan adanya abnormal return yang signifikan.

Motivasi peneliti untuk melakukan penelitian tentang topik ini adalah: pertama, penelitian mengenai kandungan informasi dividen yang 
pernah dilakukan di Indonesia memberikan hasil yang berlainan. Oleh karena itu peneliti tertarik untuk melakukan penelitian lebih lanjut. Kedua, penelitian yang pernah dilakukan terdahulu hanya menguji kandungan informasi dari pengumuman dividen, tetapi tidak menguji apakah reaksi harga saham disebabkan oleh pengumuman perubahan dividen yang dibayarkan oleh perusahaan. Oleh karena itu peneliti ingin mengujinya, karena bila pengumuman perubahan dividend mengandung informasi maka dapat mengubah ekspektasi investor tentang prospek perusahaan di masa yang akan datang.

Di samping itu peneliti juga ingin menguji apakah reaksi harga saham dipengaruhi oleh dividend yield, karena berdasarkan pengembangan teori terbaru mengenai reaksi harga saham terhadap perubahan dividen yang dilakukan Miller dan Rock, John dan William (1985) menunjukkan bahwa dividen merupakan fungsi dari variabel spesifik perusahaan.

Berdasarkan penjelasan di atas, maka perumusan masalah dalam penelitian ini adalah: pertama, apakah harga saham bereaksi positif (negatif) terhadap pengumuman kenaikan (penurunan) dividen tunai yang dibayarkan. Kedua, apakah reaksi harga saham dipengaruhi oleh dividen yield.

\section{DIVIDEND SIGNALING THEORY}

Kebijakan dividen merupakan suatu kebijakan yang penting dan harus dipertimbangkan matang-matang oleh manajemen, karena kebijakan dividen akan melibatkan kepentingan pemegang saham dengan dividennya dan kepentingan perusahaan dengan laba ditahannya. Pada hakikatnya kebijakan dividen merupakan penentuan berapa banyak laba yang diperoleh akan dibagikan kepada pemegang saham sebagai dividen, dan berapa banyak laba yang akan ditahan untuk reinvestasi.

Apabila perusahaan memilih akan membagi sebagian besar labanya sebagai dividen maka laba yang ditahan akan kecil, dengan demikian kemampuan pembentukan dana intern akan kecil, hal ini dapat menghambat pertumbuhan dalam pendapatan dan harga saham. Sebaliknya bila perusahaan memilih untuk menahan sebagian besar labanya maka laba yang dibagikan sebagai dividen akan kecil. Oleh karena itu perusahaan dalam mengambil keputusan tentang kebijakan deviden harus dapat menyeimbangkan antara kedua kepentingan tersebut, yaitu antara tingkat pertumbuhan perusahaan dan dividen yang dibayarkan kepada pemegang saham.

Faktor-faktor yang perlu dipertimbangkan perusahaan dalam melakukan kebijakan dividen menurut Weston dan Copeland (1992) dan Husnan (1994) adalah sebagai berikut: pertama, undang-undang yang mengatur bahwa dividen harus dibayarkan dari laba, baik laba tahun berjalan 
maupun laba tahun lalu yang ada dalam pos laba ditahan (retained earning) dalam neraca. Di samping itu juga ada ketentuan yang melindungi kreditur yaitu adanya larangan pembayaran dividen bila perusahaan dalam keadaan pailit dan larangan pengurangan modal untuk membayar dividen. Kedua, posisi likuiditas perusahaan. Artinya bila perusahaan berada pada posisi likuiditas yang kurang menguntungkan sebagai akibat dari laba ditahan yang sudah diinvestasikan pada aktiva tetap dan tidak disimpan dalam bentuk kas, maka perusahaan mungkin tidak dapat membagi dividen kas. Perusahaan yang sedang berkembang, di mana sebagian besar labanya digunakan untuk reinvestasi maka dalam keadaan seperti ini perusahaan dapat memutuskan untuk tidak membayar dividen. Ketiga, apabila manajemen memutuskan untuk melunasi hutang-hutangnya yang sudah jatuh tempo, maka perusahaan perlu menahan laba yang diperoleh dalam jumlah yang besar, dengan demikian dividen yang dibayarkan menjadi kecil. Keempat, bagi perusahaan yang mengalami perkembangan yang cepat akan membutuhkan banyak dana untuk membiayai ekspansinya, biasanya kebutuhan dana ini diperoleh dari sumber intern yaitu dari laba. Untuk keperluan itu maka perusahaan akan menahan labanya dari pada dibayarkan sebagai dividen. Apabila perusahaan mencari laba dari sumber ekstern, maka sumber-sumbernya adalah para pemegang saham itu sendiri, yang telah mengetahui keadaan perusahaan. Kelima, stabilitas laba suatu perusahaan mempengaruhi besar kecilnya dividen yang dibayarkan. Bagi perusahaan yang mempunyai laba relatif stabil, maka perusahaan bisa membagi dividen yang tinggi tanpa khawatir nantinya harus menurunkan dividen, karena tiba-tiba laba merosot cukup besar. Sebaliknya perusahaan yang labanya berfluktuasi atau relatif tidak stabil cenderung menahan sebagian besar labanya, karena tidak yakin apakah laba yang diharapkan di tahun-tahun yang akan datang dapat tercapai. Perusahaan semacam ini akan membayar dividen yang rendah untuk memungkinkan membelanjai rencana-rencana investasinya dengan dana intern. Keenam, bagi perusahaan besar yang sudah mapan dan mempunyai catatan profitabilitas yang baik dan laba yang stabil, maka mempunyai peluang yang lebih besar untuk masuk ke pasar modal dan bentuk-bentuk pembiayaan eksternal lainnya dibandingkan dengan perusahaan kecil yang baru. Sehingga perusahaan yang sudah mapan cenderung mempunyai tingkat pembayaran dividen yang lebih tinggi dibandingkan dengan perusahaan kecil dan baru, karena perusahaan kecil dan baru membiayai investasinya dengan dana intern. Ketujuh, bila perusahaan menerbitkan saham baru, maka pemilik saham lama akan mempunyai proporsi kepemilikan yang semakin kecil, akibatnya kendali terhadap perusahaan oleh pemilik saham lama akan berkurang. Oleh karena itu untuk mempertahankan kendali perusahaan maka pembiayaan 
terhadap investasi dilakukan dengan dana intern sehingga dividen yang dibayarkan kecil. Kedelapan, posisi pemilik perusahaan sebagai pembayar pajak sangat mempengaruhi kebijakan dividen yang dilakukan perusahaan. Pada saat tertentu, terjadi konflik kepentingan antara pemegang saham yang terkena tarif pajak tinggi dengan pemegang saham yang terkena tarif pajak rendah. Kelompok pertama ingin pembagian dividen yang rendah dan menahan sebagian besar laba, sedangkan kelompok kedua menginginkan pembagian dividen yang tinggi. Oleh karena itu, kebijakan dividen yang dapat dijalankan perusahaan adalah dengan cara kompromi dari kedua kelompok tersebut, yaitu ratio pembayaran menengah.

Ada beberapa teori yang dapat digunakan oleh perusahaan untuk menerangkan bahwa dividen yang dibayarkan digunakan sebagai isyarat mengenai prospek perusahaan di masa yang akan datang. Dalam penelitian ini, digunakan dividend signaling theory sebagai kerangka teorinya, karena teori ini relevan dengan tujuan penelitian, yaitu untuk membuktikan bahwa pengumuman pembayaran dividen mengandung informasi.

Dividend signaling theory berdasarkan pada asumsi bahwa dividen diperlukan untuk memberikan informasi positif dari manajer yang mempunyai informasi yang lengkap tentang kondisi perusahaan yang sebenarnya kepada investor yang miskin akan informasi tentang kondisi perusahaan yang sebenarnya. Fenomena seperti ini terjadi karena adanya asymmetric information antara manajer dengan investor.

Dividend signaling theory diperkenalkan oleh Ross (1977) kemudian dikembangkan oleh Bhattacharya (1979), Miller dan Rock (1985) serta John dan William (1985).

Ross (1977) berpendapat bahwa manajer sebagai orang dalam yang mempunyai informasi yang lengkap tentang arus kas perusahaan, akan memilih untuk menciptakan isyarat yang jelas mengenai masa depan perusahaan apabila mereka mempunyai dorongan yang tepat untuk melakukannya. Ross membuktikan bahwa kenaikan pada dividen yang dibayarkan dapat menimbulkan isyarat yang jelas kepada pasar bahwa prospek perusahaan telah mengalami kemajuan.

Dikatakan oleh Ross, agar suatu isyarat bermanfaat harus memenuhi empat hal. Pertama, manajemen harus selalu mempunyai dorongan yang tepat untuk mengirimkan isyarat yang jujur, walaupun beritanya buruk. Kedua, isyarat dari suatu perusahaan yang sukses tidak mudah diterima oleh pesaingnya yang kurang sukses. Ketiga, isyarat itu harus mempunyai hubungan yang cukup berarti dengan kejadian yang dapat diamati (misalnya dividen yang lebih tinggi saat ini akan dihubungkan dengan arus kas yang tinggi di masa yang akan datang). Keempat, tidak ada cara menekan biaya yang lebih efektif dari pada pengiriman isyarat yang sama. 
Selanjutnya Dividend signaling theory dikembangkan oleh Bhattacharya (1979) yaitu model yang dapat digunakan untuk menjelaskan mengapa perusahaan-perusahaan menggunakan dividen untuk memberikan isyarat walaupun menanggung kerugian saat melaksanakannya. Membagikan kas untuk pembayaran dividen merupakan hal yang mahal, karena perusahaan harus mampu menghasilkan kas yang cukup untuk mendukung pembayaran dividen secara tetap, dan karena kas dibayarkan untuk dividen maka akan mengurangi kesempatan berinvestasi dengan NPV positif. Namun demikian bagi perusahaan yang prospeknya bagus dapat mengganti biaya ini (pembayaran dividen) melalui pengeluaran saham secara bertahap dengan harga yang semakin meningkat. Tetapi bagi perusahaan yang kurang sukses tidak dapat melakukan hal yang sama. Dengan demikian, memberikan isyarat melalui nilai dividen memberikan hasil yang positif.

Miller dan Rock (1985), John dan William (1985) juga mengembangkan teori tentang dividen sebagai isyarat. Miller dan Rock menjelaskan bahwa pengumuman dividen memberikan informasi penting untuk membentuk pendapatan perusahaan saat ini yang akhirnya menjadi dasar untuk memprediksi pendapatan-pendapatan di masa yang akan datang. Sedangkan John dan William menekankan pentingnya faktor pembayaran pajak pribadi atas pendapatan dividen, pada saat pembayaran dividen sebagai isyarat yang meyakinkan.

Penggunaan dividen sebagai alat untuk mengirimkan isyarat yang nyata kepada pasar mengenai hasil kerja perusahaan pada masa mendatang merupakan cara yang tepat, walaupun mahal tetapi berarti. Hanya perusahaan yang prospeknya baik yang dapat melakukan ini. Sedangkan perusahaan-perusahaan yang tidak sukses sulit untuk meniru cara ini, karena mereka tidak mempunyai arus kas yang cukup untuk melakukannya. Dengan demikian pasar akan bereaksi terhadap perubahan dividen yang dibayarkan, karena pasar yakin bahwa pemberi isyarat adalah perusahaan yang sukses.

Penelitian mengenai kandungan informasi dividen yang telah dilakukan terdahulu memberikan hasil yang berlainan, tetapi pada umumnya hasil penelitian tersebut menunjukkan bahwa dividen mengandung informasi, artinya pengumuman perubahan dividen yang dibayarkan menyebabkan adanya reaksi harga saham dengan kata lain abnormal return yang diberikan di sekitar hari pengumuman dividen signifikan. Seperti penelitian yang dilakukan oleh Petit (1972), Aharony dan Swary (1980), Woolridge (1983), Asquith dan Mullins (1983), Healy dan Palepu (1988), Eades, Hess dan Kim (1984), Dhillon dan Johnson (1994), Sujoko (1999). Namun demikian ada beberapa penelitian yang memberikan hasil yang menunjukkan bahwa dividen tidak mengandung informasi, artinya abnormal return 
yang diberikan ke pasar tidak signifikan. Seperti penelitian yang dilakukan oleh Watts (1972), Gonedes (1978), Amsari (1993) dan Soetjipto (1997).

\section{PENGEMBANGAN HIPOTESIS}

Hipotesis kandungan informasi dividen menyatakan bahwa perubahan dividen yang dibayarkan memberikan informasi atau isyarat kepada para investor mengenai prakiraan manajemen atas laba perusahaan di masa yang akan datang. Para investor tahu bahwa para manajer enggan untuk menurunkan dividen, sehingga mereka tidak akan menaikkan dividen kecuali bila mereka yakin akan memperoleh laba yang lebih tinggi di masa yang akan datang. Oleh karena itu perubahan dividen yang dibayarkan dapat merubah ekspektasi para investor tentang prospek perusahaan di masa yang akan datang sehingga akan menimbulkan reaksi, reaksi tercermin pada harga saham.

Kenaikan dividen yang dibayarkan lebih tinggi dari yang diperkirakan merupakan isyarat bagi investor bahwa manajemen perusahaan memperkirakan laba di masa datang meningkat, hal ini akan menimbulkan reaksi positif sehingga harga saham naik. Sebaliknya, penurunan dividen atau kenaikan dividen yang lebih kecil dari yang diperkirakan merupakan suatu isyarat bahwa manajemen meramalkan laba di masa yang akan datang rendah, hal ini akan menyebabkan reaksi negatif sehingga harga saham turun. Perubahan harga saham setelah pembagian dividen menunjukkan bahwa dividen mengandung informasi atau pengisyaratan yang penting dalam pengumuman dividen tersebut (Brigham dan Houston, 1998).

Pada umumnya penelitian terdahulu mengenai kandungan informasi atau pengisyaratan dari dividen berkesimpulan bahwa perubahan dividen yang tidak terduga ditafsirkan oleh pasar sebagai isyarat prospek masa depan perusahaan. Gejala ini dijelaskan dengan menggunakan teori dividen sebagai isyarat. Dividend signalling theory yang dikemukakan oleh Bhattacharya (1979) merupakan salah satu model yang mendasari dugaan bahwa perubahan dividen yang dibayarkan mempunyai kandungan informasi. Model ini menjelaskan bahwa informasi dividen digunakan oleh investor sebagai isyarat tentang prospek perusahaan di masa yang akan datang. Hal ini terjadi karena adanya informasi yang tidak simetris antara manajer dengan investor. Manajer mempunyai informasi yang lebih lengkap tentang kondisi perusahaan dibandingkan investor, sehingga investor menggunakan kebijakan dividen yang dibayarkan oleh perusahaan sebagai indikator tentang prospek perusahaan di masa yang akan datang.

Kandungan informasi dari perubahan dividen tunai yang dibayarkan bisa menjadi fungsi dari yield perusahaan yang dapat mempengaruhi reaksi harga saham. Penggunaan yield sebagai variabel penjelas terhadap 
reaksi harga saham menurut Fehr dan Peterson (1988) mempunyai alasan sebagai berikut: pertama, yield sebagai proxy untuk persistence parameter dalam model Miller dan Rock atau bagi investor, artinya yield merupakan suatu ukuran dari tingkat dimana unexpected earning pada periode saat ini diharapkan untuk berlanjut ke periode berikutnya. dan menjadi variabel spesifik perusahaan dalam model John dan William. Kedua, bukti menunjukkan bahwa respon harga saham terhadap dividen dan event-event yang berkaitan merupakan fungsi dari yield mereka. Ketiga, Litzenberger dan Ramaswamy membuktikan suatu hubungan langsung antara return saham dan dividend yield dalam konteks penilaian capital assets setelah pajak.

Berdasarkan pada teori dan bukti-bukti empiris tentang kandungan informasi dividen, dirumuskanlah hipotesis sebagai berikut:

1. Reaksi harga saham positif (negatif) bila terjadi kenaikan (penurunan) dividen.

2. Reaksi harga saham dipengaruhi oleh dividend yield.

\section{METODE PENELITIAN}

\section{Sampel dan Data}

Dalam penelitian ini sampel yang digunakan terdiri dari 52 perusahaan yang terbagi atas dua kelompok, yaitu kelompok perusahaan yang membayar dividen meningkat yang terdiri dari 27 perusahaan dan perusahaan yang membayar dividen menurun yang terdiri dari 25 perusahaan, daftar perusahaan lihat lampiran 1. Kenaikan dan penurunan dividen yang dibayarkan dilihat dari dividen yang dibayarkan pada tahun 1995 dan 1996.

Sampel yang digunakan dalam penelitian ini dipilih dengan menggunakan metode purposive sampling dari populasi yang terdiri dari perusahaan-perusahaan yang terdaftar di BEJ yang membayar dividen pada tahun 1995 dan 1996. Adapun proses pemilihan sampel yang digunakan melalui tahap-tahap sebagai berikut: pertama, dipilih perusahaan-perusahan yang membayar dividen tunai pada tahun 1995 dan 1996. Kedua, dari perusahaan-perusahaan tersebut dipilih perusahaan yang membayar dividen meningkat dan dividen menurun pada tahun 1996. Ketiga, dari perusahaan yang membayar dividen meningkat dan menurun kemudian dipilih perusahaan-perusahaan yang sahamnya aktif diperdagangkan di BEJ, hal ini ditunjukkan dari harga saham harian yang relatif berfluktuasi. Perusahaan-perusahaan yang terpilih inilah yang dijadikan sampel dalam penelitian ini.

Data yang digunakan dalam penelitian ini adalah data sekunder yang berupa data harga saham harian, data indeks harga saham gabungan, data dividend yield dan data dividen per share. Data-data tersebut 
diambil dari berbagai sumber, seperti dari fact book 1996 dan 1997, JSX Monthly Statistics, database PACAP.

\section{Model Empiris}

a. Return realisasi saham individual $\left(\mathrm{Ri}_{\mathrm{t}}\right)$ selama periode estimasi dan periode peristiwa dihitung dengan menggunakan rumus berikut ini:

$\mathbf{R}_{\mathrm{it}}=\left(\mathrm{P}_{\mathrm{i}, \mathrm{t}}-\mathrm{P}_{\mathrm{i}, \mathrm{t}-\mathrm{1}}\right) / \mathrm{P}_{\mathrm{i}, \mathrm{t}-\mathrm{1}}$ Notasi:

$\mathrm{P}_{\mathrm{i}, \mathrm{t}} \quad=$ harga saham ke $\mathrm{i}$ hari ke $\mathrm{t}$

$\mathrm{P}_{\mathrm{i}, \mathrm{t}-\mathrm{1}} \quad=$ harga saham ke $\mathrm{i}$ hari ke $\mathrm{t}-1$

b. Return indeks pasar saham $\left(R_{m, t}\right)$ selama periode estimasi dan periode peristiwa dihitung dengan menggunakan rumus berikut ini :

$R_{\mathrm{m}, \mathrm{t}}=\left(\mathrm{IHSG}_{\mathrm{t}}-\mathrm{IHSG}_{\mathrm{t}-1}\right) / \mathrm{IHSG} \mathrm{t}_{\mathrm{t}-1}$

Notasi:

$\mathrm{HSG}_{\mathrm{t}}=$ indeks pasar hari ke $\mathrm{t}$

$\mathrm{HSG}_{\mathrm{t}-1}=$ indeks pasar hari ke $\mathrm{t}-1$

c. Return ekspektasi saham $[\mathrm{E}(\mathrm{R} i, \mathrm{t})]$ dihitung dengan menggunakan market model (model pasar), dilakukan dengan dua tahap yaitu, pertama membentuk model ekspektasi. Model ekspektasi dibentuk dengan menggunakan teknik regresi OLS (Ordinary Least Square) dan diperoleh persamaan sebagai berikut: $\mathbf{E}\left(\mathbf{R}_{\mathrm{i}, \mathrm{t}}\right)=\alpha_{\mathrm{i}}+\beta_{\mathrm{i}} \mathbf{R}_{\mathrm{mt}}$ Notasi:

$E\left(R_{i, t}\right)=$ Return ekspektasi saham ke i pada periode $t$

$\alpha$ l = intercept saham ke $\mathrm{i}$

$\beta \mathrm{I} \quad=$ beta saham ke $\mathrm{i}$

$\mathrm{R}_{\mathrm{mt}} \quad=$ return indeks pasar pada periode $\mathrm{t}$

Kedua, dengan menggunakan model ekspektasi di atas, return ekspektasi masing-masing saham selama periode peristiwa dihitung, caranya dengan mensubstitusikan nilai return indeks pasar harian $\left(R_{m t}\right)$ ke dalam persamaan tersebut.

d. Abnormal return dihitung dari selisih antara return realisasi dengan return ekspektasi, dengan rumus sebagai berikut:

$A R_{i, t}=R_{i, t}-E\left(R_{i, t}\right)$

Notasi:

$A R_{i, t} \quad=$ abnormal return saham ke i hari ke $t$

$\mathrm{R}_{\mathrm{i}, \mathrm{t}} \quad=$ return realisasi saham ke $\mathrm{i}$ hari ke $\mathrm{t}$

$E\left(R_{i, t}\right) \quad=$ return ekspektasi saham ke $\mathrm{i}$ hari ke $\mathrm{t}$

e. Standardized Abnormal Return masing-masing saham selama periode peristiwa dihitung dengan rumus sebagai berikut:

$$
\mathrm{SAR}_{\mathrm{i}, \mathrm{t}}=\frac{\mathrm{AR}_{\mathrm{i}, \mathrm{t}}}{\mathrm{KSE}_{\mathrm{adj}-\mathrm{i}}}
$$

Notasi: 


$$
\begin{array}{ll}
\mathrm{SAR}_{\mathrm{i}, \mathrm{t}} & =\text { standardized abnormal return saham ke } \mathrm{i} \text { hari } \mathrm{ke} \mathrm{t} \\
\mathrm{AR}_{\mathrm{i}, \mathrm{t}} & =\text { abnormal return saham ke } \mathrm{i} \text { hari ke } \mathrm{t} \\
\mathrm{KSE}_{\text {adj-i }} & =\text { kesalahan standar estimasi saham ke } \mathrm{i}
\end{array}
$$

\section{HASIL PENELITIAN}

\section{Pengujian Hipotesis Kandungan Informasi Dividen}

Pengujian ini dilakukan untuk mengetahui apakah pasar bereaksi positif (negatif) terhadap pengumuman kenaikan (penurunan) dividen yang dibayarkan di seputar hari peristiwa, yaitu lima hari sebelum pengumuman sampai dengan lima hari setelah pengumuman. Hasil pengujian digunakan sebagai dasar untuk mengatakan bahwa pengumuman dividen mengandung informasi atau tidak.

Hasil pengujian abnormal return dividen naik secara statistik dapat dilihat pada tabel 4.1 berikut ini.

Tabel 4.1

Hasil pengujian Abnormal Return Dividen Naik Selama Periode Peristiwa

\begin{tabular}{|c|c|c|c|c|}
\hline $\begin{array}{c}\text { Hari } \\
\text { ke-t }\end{array}$ & AAR & $\mathbf{t}_{\text {hitung }}$ & $\mathbf{t}_{\text {tabel }}$ & Keputusan \\
\hline-5 & 0,4283 & 1,903 & 1,706 & Ho ditolak \\
\hline-4 & $-0,0932$ & $-0,513$ & 1,706 & Ho diterima \\
\hline-3 & 0,3536 & 1,128 & 1,706 & Ho diterima \\
\hline-2 & $-0,4810$ & $-1,842$ & 1,706 & Ho diterima \\
\hline-1 & $-0,2778$ & $-0,725$ & 1,706 & Ho diterima \\
\hline 0 & 0,0665 & 0,417 & 1,706 & Ho diterima \\
\hline+1 & 0,1803 & 0,981 & 1,706 & Ho diterima \\
\hline+2 & $-0,0971$ & $-0,329$ & 1,706 & Ho diterima \\
\hline+3 & 0,2635 & 1,433 & 1,706 & Ho diterima \\
\hline+4 & $-0,4015$ & $-0,968$ & 1,706 & Ho diterima \\
\hline+5 & $-0,3057$ & $-0,827$ & 1,706 & Ho diterima \\
\hline
\end{tabular}

Tabel 4.1 menyajikan ringkasan hasil pengujian hipotesis kandungan informasi kenaikan dividen yang dibayarkan di seputar hari peristiwa, yaitu lima hari sebelum peristiwa sampai dengan lima hari setelah peristiwa. Pengujian dilakukan dengan menggunakan t-test uji sisi kanan, dengan tingkat signifikansi $(\alpha)$ sebesar $5 \%$ (nilai t tabel 1,706).

Dari hasil pengujian yang terlihat pada tabel 4.1 ternyata hanya ada satu abnormal return yang berada di daerah penolakan $\mathrm{Ho}$ atau menerima $\mathrm{H}_{1}$, yaitu pada hari kelima sebelum pengumuman kenaikan dividen (t5), di mana nilai t hitung yang dihasilkan lebih besar dari 1,706. Hal ini menunjukkan bahwa lima hari sebelum pengumuman peristiwa informasi 
sudah lebih dulu bocor ke publik yang ditunjukkan oleh reaksi harga saham yang positif dan signifikan pada hari -5 . Kebocoran informasi terjadi karena pada dividen naik reaksi yang diharapkan terjadi positif, sehingga para investor mencoba untuk mengakses informasi ke dalam perusahaan dan menggunakan informasi tersebut untuk melakukan transaksi akibatnya reaksi terjadi sebelum pengumuman dilakukan.

Abnormal return pada hari kelima sebelum peristiwa (t-5) sebesar 0,4283 secara statistik signifikan pada alpha $(\alpha)$ sebesar $5 \%$, ini menunjukkan bahwa harga saham bereaksi positif terhadap pengumuman kenaikan pembayaran dividen, hal ini sesuai dengan teori yang mengatakan bahwa dividen merupakan signal bagi investor, Di mana kenaikan dividen diinterpretasikan sebagai signal prospek perusahaan di masa yang akan datang lebih baik atau lebih menguntungkan dari saat ini.

Hasil pengujian abnormal return dividen turun secara statistik dapat dilihat pada tabel 4.2 berikut ini.

Tabel 4.2

Hasil Pengujian Abnormal Return Dividen Turun Selama Periode Peristiwa

\begin{tabular}{|c|c|c|c|c|}
\hline $\begin{array}{c}\text { Hari } \\
\text { ke-t }\end{array}$ & $\mathbf{A A R}_{\mathbf{t}}$ & $\mathbf{T}_{\text {hitung }}$ & $\mathbf{t}_{\text {tabel }}$ & Keputusan \\
\hline-5 & 0,2154 & 1,392 & $-1,711$ & Ho diterima \\
\hline-4 & $-0,0248$ & $-0,169$ & $-1,711$ & Ho diterima \\
\hline-3 & 0,1091 & 0,555 & $-1,711$ & Ho diterima \\
\hline-2 & $-0,1156$ & $-0,578$ & $-1,711$ & Ho diterima \\
\hline-1 & 0,3754 & 1,370 & $-1,711$ & Ho diterima \\
\hline 0 & 0,6120 & 1,618 & $-1,711$ & Ho diterima \\
\hline+1 & $-0,1600$ & $-1,064$ & $-1,711$ & Ho diterima \\
\hline+2 & 0,2373 & 0,867 & $-1,711$ & Ho diterima \\
\hline+3 & 0,0364 & 0,179 & $-1,711$ & Ho diterima \\
\hline+4 & 0,0451 & 0,245 & $-1,711$ & Ho diterima \\
\hline+5 & $-0,2983$ & $-1,755$ & $-1,711$ & Ho ditolak \\
\hline
\end{tabular}

Tabel 4.2 menyajikan ringkasan hasil pengujian hipotesis kandungan informasi penurunan dividen yang dibayarkan di seputar hari peristiwa, yaitu lima hari sebelum peristiwa sampai dengan lima hari setelah peristiwa dengan menggunakan t-test uji sisi kiri, dengan menggunakan tingkat signifikansi $(\alpha)$ sebesar $5 \%$ (nilai t tabel $-1,711$ ).

Dari hasil pengujian yang terlihat pada tabel 4.2 ternyata hanya ada satu abnormal return yang berada di daerah penolakan $\mathrm{Ho}$ atau menerima $\mathrm{H}_{1}$, yaitu pada hari kelima setelah pengumuman penurunan dividen $(t+5)$, di mana nilai t hitung yang dihasilkan lebih kecil dari $-1,711$. Hal ini 
menunjukkan bahwa pada hari kelima setelah pengumuman peristiwa masih adanya distribusi informasi yang belum simetris, yang ditunjukkan oleh reaksi harga saham negatif dan signifikan pada hari +5 .

Abnormal return pada hari kelima setelah peristiwa $(t+5)$ sebesar $-0,2983$ secara statistik signifikan pada alpha $(\alpha)$ sebesar $5 \%$, ini menunjukkan bahwa harga saham bereaksi negatif terhadap pengumuman penurunan pembayaran dividen, hal ini sesuai dengan teori yang mengatakan bahwa dividen merupakan signal bagi investor, Di mana penurunan dividen diinterpretasikan sebagai signal prospek perusahaan di masa yang akan datang lebih buruk atau kurang menguntungkan daripada saat ini.

\section{Pengujian Hipotesis Pengaruh dividend yield terhadap reaksi harga saham.}

Pengujian ini dilakukan karena terdapat abnormal return yang signifikan di periode peristiwa. Pengujian dilakukan dengan menggunakan model cross sectional regression antara standardized cumulative abnormal return dengan dividend yield yang dihipotesiskan akan mempengaruhi abnormal return. Dividend yield terdiri dari Relatif yield (RELYLD) dan Cash yield (CYLD).

- $R E L Y L D=\frac{\text { dividend yield perusahaan }}{\text { rata }- \text { ratadividend yield pasar }}$

- $R E L Y L D=\frac{\text { perubahan dividend per lembar saham }}{\begin{array}{c}\text { harga saham penutupan pada saat } \\ \text { peristiwa pengumuman } R \text { RUS }\end{array}}$

Pengaruh dividend yield terhadap abnormal return dapat secara individual maupun secara bersamaan. Untuk melihat pengaruh individual dividend yield terhadap reaksi harga saham, digunakan persamaan sebagai berikut:

$$
\begin{aligned}
& \text { SCAR }_{i t}=\alpha_{1}+\beta_{1} \text { RELYLD }_{i}+\varepsilon_{1 i} \\
& \text { SCAR }_{i t}=\alpha_{2}+\beta_{2} \text { CYLD }_{i}+\varepsilon_{2 i} \ldots . . .
\end{aligned}
$$

Untuk melihat pengaruh kombinasi dividend yield terhadap reaksi harga saham, digunakan persamaan sebagai berikut:

$$
\text { SCAR }_{\mathrm{i}, \mathrm{t}}=\alpha_{3}+\beta_{3} \text { RELYLD }_{\mathrm{i}}+\beta_{4} \text { CYLD }_{\mathrm{i}}+\varepsilon_{3 \mathrm{i}}
$$

Dividen yield dikatakan mempengaruhi abnormal return bila koefisien regresi signifikan ( $\mathrm{H}_{0}$ ditolak) tetapi bila koefisien regresi tidak signifikan (Ho diterima) berarti dividen yield tidak berpengaruh terhadap abnormal return.

Berdasarkan hasil perhitungan regresi yang dilakukan dengan menggunakan program SPSS di peroleh hasil sebagai berikut: 
Tabel 4.3

Persamaman Regresi Untuk Dividen Naik

\begin{tabular}{|c|c|c|c|c|c|}
\hline Persamaan & Konstanta & $\begin{array}{c}\text { Koefisien } \\
\text { RELYLD }\end{array}$ & $\begin{array}{c}\text { Koefisien } \\
\text { CYLD }\end{array}$ & $\mathbf{F}$ & $\mathbf{R}^{2}$ \\
\hline 8 & 0,726 & $-0,230$ & & 1,007 & 0,039 \\
$(1,949)$ & $(-1,004)$ & & & \\
9 & 0,574 & & $-0,079$ & 0,407 & 0,016 \\
& $(1,781)$ & & $(-0,638)$ & & \\
10 & 0,737 & $-0,211$ & $-0,02$ & 0,493 & 0,039 \\
& $(1,896)$ & $(-0,765)$ & $(-0,132)$ & & \\
\hline
\end{tabular}

* (...) nilai thitung

Dari tabel 4.3 terlihat bahwa pada dividen naik, pengaruh relatif yield terhadap abnormal return sebesar $-0,230$ (persamaan. 8) sedangkan pengaruh cash yield terhadap abnormal return sebesar $-0,079$ (persamaan 9). Pengaruh relatif yield dan cash yield secara bersamaan terhadap abnormal return sebesar $-0,211$ dan $-0,02$ (pers 10), hal ini tidak sesuai dengan yang diharapkan karena pengaruh yang diharapkan adalah positif. Hasil ini sesuai dengan hasil pengujian terhadap koefisien regresinya.

Berdasarkan hasil pengujian koefisien regresinya ditunjukkan bahwa pada $\alpha=5 \%$ relatif yield tidak mempunyai pengaruh positif yang signifikan terhadap abnormal return, ini ditunjukkan oleh nilai t hitung yang dihasilkan lebih kecil dari nilai t tabel $(-1,004<1,706)$. Oleh karena itu dapat disimpulkan bahwa relatif yield tidak berpengaruh terhadap abnormal return.

Berdasarkan hasil pengujian koefisien regresinya ditunjukkan bahwa pada $\alpha=5 \%$ cash yield tidak mempunyai pengaruh positif yang signifikan terhadap abnormal return, ini ditunjukkan oleh nilai t hitung yang dihasilkan lebih kecil dari nilai t tabel $(-0,638<1,706)$. Oleh karena itu dapat disimpulkan bahwa cash yield tidak berpengaruh terhadap abnormal return.

Berdasarkan hasil pengujian koefisien regresinya ditunjukkan bahwa pada $\alpha=5 \%$ relatif yield dan cash yield tidak mempunyai pengaruh positif yang signifikan terhadap abnormal return, ini ditunjukkan oleh nilai $t$ hitung keduanya lebih kecil dari nilai t tabel $(-0,765$ dan $-0,132<1,706)$. Oleh karena itu dapat disimpulkan bahwa relatif yield dan cash yield secara bersama-sama tidak berpengaruh terhadap abnormal return. 
Tabel 4.4

Persamaman Regresi Untuk Dividen Turun

\begin{tabular}{|c|c|c|c|c|c|}
\hline Persamaan & Konstanta & $\begin{array}{c}\text { Koefisien } \\
\text { RELYLD }\end{array}$ & $\begin{array}{c}\text { Koefisien } \\
\text { CYLD }\end{array}$ & $\mathbf{F}$ & $\mathbf{R}^{\mathbf{2}}$ \\
\hline 8 & $-0,431$ & 0,142 & & 0,641 & 0,027 \\
& $(-1,809)$ & $(0,801)$ & & & \\
9 & $-0,041$ & & 0,071 & 1,561 & 0,064 \\
& $(-0,153)$ & & $(1,249)$ & & \\
10 & $-0,173$ & 0,224 & 0,092 & 1,575 & 0,125 \\
& $(-0,610)$ & $(1,245)$ & $(1,571)$ & & \\
\hline
\end{tabular}

* (...) nilai thitung

Dari tabel 4.4 terlihat bahwa pada dividen turun, pengaruh relatif yield terhadap abnormal return sebesar 0,142 (pers 8), sedangkan pengaruh cash yield terhadap abnormal return sebesar 0,071 (pers 9). Pengaruh relatif yield dan cash yield secara bersamaan terhadap abnormal return sebesar 0,224 dan 0,092 (pers 10), hal ini tidak sesuai dengan yang diharapkan karena pengaruh yang diharapkan adalah negatif. Hasil ini sesuai dengan hasil pengujian koefisien regresinya.

Berdasarkan hasil pengujian koefisien regresinya ditunjukkan bahwa pada $\alpha=5 \%$ relatif yield tidak mempunyai pengaruh negatif yang signifikan terhadap abnormal return, ini ditunjukkan oleh nilai t hitung yang dihasilkan lebih besar dari nilai t tabel $(0,801>-1,711)$. Oleh karena itu dapat disimpulkan bahwa relatif yield tidak berpengaruh terhadap abnormal return.

Berdasarkan hasil pengujian koefisien regresinya ditunjukkan bahwa pada $\alpha=5 \%$ cash yield tidak mempunyai pengaruh negatif yang signifikan terhadap abnormal return, ini ditunjukkan oleh nilai t hitung yang dihasilkan lebih besar dari nilai $t$ tabel $(1,249>-1,711)$ Oleh karena itu dapat disimpulkan bahwa cash yield tidak berpengaruh terhadap abnormal return.

Berdasarkan hasil pengujian koefisien regresinya ditunjukkan bahwa pada $\alpha=5 \%$ relatif yield dan cash yield tidak mempunyai pengaruh negatif yang signifikan terhadap abnormal return, ini ditunjukkan oleh nilai t hitung keduanya lebih besar dari nilai t tabel, masing-masing sebesar 1,245 dan 1,571. Oleh karena itu dapat disimpulkan bahwa relatif yield dan cash yield secara bersama-sama tidak berpengaruh terhadap abnormal return. 


\section{PENUTUP}

Berdasarkan hasil analisis dari hipotesis yang ada dalam penelitian ini, maka dapat diambil kesimpulan sebagai berikut:

1. Abnormal return yang signifikan terjadi pada peristiwa kenaikan dividen maupun peristiwa penurunan dividen, yaitu pada hari kelima sebelum pengumuman dividen naik dan hari kelima setelah pengumuman dividen turun. Ini menunjukkan bahwa pengumuman perubahan dividen tunai mengandung informasi.

2. Berdasarkan hasil pengujian yang dilakukan terhadap variabel spesifik perusahaan yang berupa dividend yield menunjukkan bahwa relatif yield dan cash yield baik secara individual maupun secara bersamasama secara signifikan tidak berpengaruh terhadap abnormal return baik untuk dividen naik maupun untuk dividen turun. Dengan demikian dapat dikatakan bahwa reaksi harga saham tidak dipengaruhi oleh dividend yield.

\section{SARAN}

1. Dari hasil pengujian yang dilakukan ternyata perubahan dividend yield tidak mempengaruhi reaksi harga saham. Untuk itu maka pada penelitian yang akan datang bisa ditambahkan variabel yang lain yang mungkin mempengaruhi reaksi harga saham, misalnya variabel ukuran perusahaan.

2. Pada penelitian ini diperoleh hasil bahwa pengumuman kenaikan maupun penurunan dividen memberikan reaksi. Sebenarnya reaksi tidak hanya disebabkan oleh karena adanya peningkatan atau penunuran dividen. Oleh karena itu pada penelitian yang akan datang pengumuman dividen dapat dikaitkan dengan prospek perusahaan. Misalnya apakah kenaikan dividen diikuti dengan kenaikan earning atau kenaikan dividen diikuti dengan penambahan investasi, apakah penurunan dividen diikuti dengan penurunan earning atau penurunan dividen diikuti dengan penambahan investasi.

3. Penelitian ini hanya menggunakan sampel sebanyak 52 perusahaan, yaitu 27 perusahaan yang membayar dividen naik dan 25 perusahaan yang membayar dividen turun dengan periode pengamatan hanya dua tahun yaitu tahun 1995 dan 1996. Jumlah sampel dan kurun waktu pengamatan ini mungkin kurang memadai untuk pengujian hipotesis yang ada. Oleh karena itu pada masa yang akan datang pengujian ini bisa dilakukan dengan menggunakan sampel yang lebih banyak dan waktu pengamatan yang lebih panjang. Hal ini mungkin akan memberikan hasil yang lebih baik. 


\section{DAFTAR PUSTAKA}

Aharony, J and I. Swary (1980), "Quarterly Dividend and Earnings Announcements and Stockholders' Returns: An Empirical Analysis", Journal of Finance, Vol XXXV, No.1, pp. 1-12.

Asquith, P and David Mullins (1983), "The Impact of Initiating Dividend Payments on Stockholders' Wealth ", Journal of Bussiness, pp. 77-96.

Bhattacharya, S (1979), "Imperfect Information, Dividend Policy, and The Bird in the Hand Fallacy ", Bill Journal of Economic, pp. 259-270.

Brigham, Eugene F and Gapenski, Louis.C (1996), " Intermediate Financial Management ", Fifth Edition, The Dryden Press, Harcourt Brace College, Orlando.

and Houston, J. F (1998), "Fundamentals of Financial Management", Eighth Edition, Harcourt Inc.

Brown, S and J Warner (1985), "Using Daily Stocks Returns: The Case of Event Studies", Journal of Financial Economics, pp. 3-31.

Dhillon, U.S and Johnson, H (1994), "The Effect of Dividend Changes on Stock and Bond Prices", Journal of Finance, Vol XLIX, No. 1, pp. 281-289.

Eades, Hess and Kim (1984), "On Interpreting Security Returns During Ex Dividen Period", Journal of Financial Economics, pp. 3-34.

Fehrs, Donald H, David R Peterson and Gary A Benesh (1988), "Evidence of a Relation Between Stock Price Reactions Around Cash Dividend Changes and Yields", Journal of Financial Research, Vol $\mathrm{XI}$, No.2, pp.111-123.

Gonedes, N.L (1978), "Corporate Signalling, External Accounting, and Extraordinary Items", Journal of Accounting Research, No 16, pp. 26-79.

Healy, P.M and K.G Palepu (1988), "Earning Information Conveyed by Dividend Initiations and Ommission", Journal of Financial Economics, No. 21, pp.149-175.

Husnan, Suad (1998), "Dasar-dasar Teori Portofolio dan Analisis Sekuritas", UPP AMP YKPN, Yogyakarta.

(1994), "Manajemen Keuangan: Teori dan Penerapan (Keputusan Jangka Panjang)", Edisi tiga, BPFE, Yogyakarta.

Indonesian Capital Market Directory 1999. 
Jakarta Stock Exchange, Fact Book 1996.

--------- 1997.

---------, JSX Statistic 1996.

John, K and J. William (1985), "Dividends, Dilutions and Taxes: A Signalling Equilibrium", Journal of Finance, pp. 1053-1070.

Jogiyanto, HM (1998), "Teori Portofolio dan Analisis Investasi", BPFE, Yogyakarta.

Miller, M and K. Rock (1985), "Dividend Policy Under Asymmetric Information", Journal of Finance, pp. 1031-1051.

Pettit, R. Richardson (1972), "Dividend Announcements, Security Performance, and Capital Market Efficiency ", Journal of Finance, Vol XXVII, No.5, pp. $993-1007$.

Ross, S.A (1977), "The Determination of Financial Structure: The Incentive Signalling Approach", Bell Journal of Economics, pp. 23-40

Van Horne, James. C (1986), "Fundamentals of Financial Management", Six Editions, Prentice Hall. Inc, USA.

Watts, R (1973), "The Information Content of Dividends", Journal of Business, No. 46, pp. 191-211.

Weston, J Fred and Thomas E Copeland (1986), "Managerial Finance", CBS College Publishing.

Woolridge, J Randall (1982), "The Information Content of Dividend Changes", Journal of Financial Research, No. 5, pp. 237-247. 